\title{
Somatic cell counts as an indicator of mammary infection in periparturient cows
}

\author{
Contagem de células somáticas como indicador de infecção mamária em vacas \\ periparturientes
}

\author{
Juliana França dos REIS ${ }^{1}$; Renata Freitas LEITE $^{1}$; Cynthia Pereira da Costa e SILVA ${ }^{1}$; Camila Costa \\ BACCILI $^{1}$; Priscilla Anne MELVILLE ${ }^{2}$; Nilson Roberti BENITES ${ }^{2}$; Viviani GOMES ${ }^{1}$ \\ ${ }^{1}$ Universidade de São Paulo, Faculdade de Medicina Veterinária e Zootecnia, Departamento de Clínica Médica, São Paulo - SP,
Brazil \\ ${ }^{2}$ Universidade de São Paulo, Faculdade de Medicina Veterinária e Zootecnia, Departamento de Medicina Veterinária Preventiva e \\ Saúde Animal, São Paulo - SP, Brazil
}

\begin{abstract}
The somatic cell count (SCC) is a screening test for the evaluation of intramammary infection; however, changes in mammary secretion during colostrogenesis can promote a physiological increase in the SCC, potentially reducing its reliability in the diagnosis of mastitis. Therefore, the aim of this study was to evaluate bovine colostrum SCC as an indicative parameter of breast infection in Holstein periparturient cows. A total of 80 samples were harvested from the first milking colostrum of 20 cows and were subjected to manual SCC and bacteriological examination. Bacterial growth was present in $36.62 \%$ of the crops; coagulase-negative Staphylococcus (CNS) was the predominant microorganism (76.92\%). The median SCC in infected cows $\left(1.8 \times 10^{6}\right.$ cells $\left./ \mathrm{mL}\right)$ was significantly higher than in uninfected cows $\left(0.9 \times 10^{6}\right.$ cells $\left./ \mathrm{mL}\right)(\mathrm{p}=0.0451)$. The sensitivity $(100-$ $15 \%)$, specificity (100-2.2\%), and false positive (100-2.2\%) of the SCC decreased gradually when thresholds of $0.2-10.0 \times 10^{6}$ cells $/ \mathrm{mL}$ were adopted. In contrast, the proportion of false negatives (0-84.6\%) revealed an opposite trend. The threshold of greatest concordance between SCC and bacteriological examination was $10.0 \times 10^{6} \mathrm{cells} / \mathrm{mL}$; however, the sensitivity rates $(15.4 \%)$, specificity $(2.2 \%)$, and false positive (2.2\%) were very low. Based on these results, we conclude that SCCs increased prior to the infectious processes of the mammary gland, particularly in the CNS group. However, physiological changes caused by colostrogenesis resulted in poor concordance between the SCC and bacteriological examination of the colostrum.

Keywords: Somatic cell count. Colostrum. Mastitis. Epidemiological indicators.
\end{abstract}

\section{Resumo}

A contagem de células somáticas (CCS) é um teste de triagem para avaliação de infecção intramamária, porém, as alterações na composição do colostro observadas durante a colostrogênese podem promover o aumento fisiológico da CCS e inviabilizar o uso desta prova para diagnóstico da mastite. Assim, o objetivo desta pesquisa foi avaliar a CCS do colostro como parâmetro indicativo de infecção mamária em vacas Holandesas periparturientes. Para tanto, foram colhidas 80 amostras de colostro de primeira ordenha, provenientes de 20 vacas, para a CCS manual e exame bacteriológico (EB). Observou-se crescimento bacteriano em 36,62\% dos cultivos, com predomínio de Staphylococcus coagulase-negativa (SCN) (76,92\%). O valor mediano da CCS de vacas infectadas $\left(1,8 \times 10^{6}\right.$ células $\left./ \mathrm{mL}\right)$ foi maior do que o obtido para as vacas sadias $\left(0,9 \times 10^{6}\right.$ células $\left./ \mathrm{mL}\right)$ $(\mathrm{P}=0,0451)$. A sensibilidade (100 a $15 \%)$, especificidade (100 a 2,2\%) e falso-positivo (100 a 2,2\%) diminuíram gradativamente quando os limiares de 0,2 a 10,0 x10 células/mL foram adotados. Em contrapartida, a proporção de falso-negativo (0 a 84,6\%) apresentou perfil inverso. O limiar de maior concordância entre a CCS e EB foi de 10,0 x10 células/mL, porém os índices de sensibilidade (15,4\%), especificidade (2,2\%) e falso-positivo (2,2\%) foram muito baixos. Com base nos resultados encontrados, conclui-se que a CCS apresentou elevação diante dos processos infecciosos da glândula mamária (GM), causados especialmente por bactérias do grupo SCN. No entanto, as alterações fisiológicas decorrentes da colostrogênese resultaram em baixa concordância entre a CCS e o exame bacteriológico do colostro.

Palavras-chave: CCS. Colostro. Mastite. Indicadores epidemiológicos. 
Correspondence to:

Juliana França dos Reis

Universidade de São Paulo, Faculdade de Medicina

Veterinária e Zootecnia, Departamento de Clínica Médica

Av. Prof. Dr. Orlando Marques de Paiva, 87

CEP 05508-270, São Paulo, SP, Brazil

e-mail: jufreis123@gmail.com

Received: 29/06/2015

Approved: 06/04/2016

\section{Introduction}

Colostrogenesis is a critical period for mammary gland (MG) health because it is associated with high infection rates in the immediate postpartum (HOGAN; SMITH, 2012). This can produce calving infection rates ranging between 7.7 and $33.3 \%$ for three weeks postpartum (SILVA et al., 2014). Colostrogenesis initiates several weeks before parturition through the active transference of immunoglobulins from the blood flow to the MG (BAUMRUCKER; BRUCKMAIER, 2014). During this process, the blood flow rate may increase, resulting in transudation and physiological edema postpartum (DENTINE; McDANIEL, 1983). These events coincide with an increase in mammary secretion cellularity $\left(0.6-0.9 \times 10^{6}\right.$ cells $/ \mathrm{mL}$ of colostrum) leading to a predominance of macrophages and epithelial cells (69.5\%), with a relatively smaller proportion of neutrophils (13.3\%) (McDONALD; ANDERSON, 1981; GOMES et al., 2011). These cells are believed to reach mammary secretion by diapedesis (BAUMRUCKER; BRUCKMAIER, 2014).

Mammary secretion composition changes during peripartum; a small proportion and activity of neutrophils has been associated with the susceptibility of MG to bacterial infections. During the immediate postpartum, the predominant microorganisms isolated from the colostrum and transition milk include Gram-positive bacteria, such as coagulasenegative Staphylococcus (CNS) and Streptococcus agalactiae (RAJALA-SCHULTZ et al., 1999; DINGWELL et al., 2002; ODENSTEN et al., 2007). These microorganisms break down the physical barrier and penetrate the teat canal, triggering the liberation of inflammatory mediators that initiate the inflammation cascade. These mediators directly influence leukocyte migration, particularly the migration of neutrophils from the blood to the site of injury. Neutrophils are responsible for the internalization and destruction of bacteria. These processes occur through the production of reactive oxygen species and hydrolytic enzymes (MADDOX et al., 1999; HODGKINSON et al., 2007).

Detection of mammary infection during peripartum is a significant challenge due to physiological edema and changes in the composition of mammary secretion. Bacteriological culture is the gold standard for identifying intramammary infection; however, the logistics and costs involved with the harvesting of samples from all quarters at parturition have limited the adoption of this strategy in the dairy industry. Consequently, the somatic cell counting (SCC) has been considered globally for the screening of mammary infection in parturient cows (SARGEANT et al., 2001). However, the utilization of colostrum SCCs in relation to bacterial culture requires validation by epidemiological markers.

The present investigation hypothesized that mammary infections could be responsible for accelerating inflammatory cell migration to the MG in the peripartum. Therefore, the aim of this study was to evaluate the bovine colostrum SCC as an indicative parameter of mammary infection during the immediate postpartum in Holstein cows.

\section{Material and Methods}

A total of 20 pregnant Holstein cows were selected for this study. Ethical approval was granted by the Ethics Committee for Animal Research at the Faculty of Veterinary Medicine and Animal Science (reference number: 2305/2011). The cows were sourced from a dairy property located in Nova Odessa, São Paulo (latitude $22^{\circ} 46^{\prime} 39^{\prime \prime}$, longitude $47^{\circ} 17^{\prime} 45^{\prime \prime}$ ), at an altitude of $580 \mathrm{~m}$. 
Immediately after calving, cows were sent to a milking parlor for colostrum sample harvesting. The teats were first cleaned and disinfected with water and $2 \%$ chlorinated solution, dried with individual paper towels, and then the teat orifices were disinfected with $70 \%$ ethanol. Two aliquots of colostrum $(n=80)$ were harvested after discarding the first jet of milk, performed via the dark field test. The first aliquot was obtained in plastic tubes $(15 \mathrm{ml})$ for the performance of a SCC; and the second aliquot was stored in sterile $5 \mathrm{ml}$ glass tubes for bacteriological examination (BE).

For the SCC, colostrum was diluted with phosphate buffered saline (PBS) solution at 1:1 and 10 $\mu \mathrm{L}$ of this mixture was distributed on a slide area of 1 $\mathrm{cm}^{2}$ in a study by Gomes et al. (2011). Slides were dried for $24 \mathrm{~h}$ at room temperature, fixed with methanol for $15 \mathrm{~min}$ and then stained according to the method by Rosenfeld (1947).

To evaluate the number of somatic cells, 100 fields were counted using an optical microscope $(\mathrm{CH} 2$ Olympus) at $1000 \times$ magnification. Data from each field were summed and multiplied by the microscope factor (4.167). This value was then multiplied by two, according to the initial sample dilution in PBS.

For BE, colostrum aliquots were plated on sheep blood agar at $5 \%$. These were then incubated in a bacteriological incubator at $37^{\circ} \mathrm{C}$ for up to $72 \mathrm{~h}$, with daily readings recorded. Samples that presented three or more isolated colonies of the same kind of microorganism were considered as positive. Positivecoagulase Staphylococcus was considered positive when it presented as one or more bacterial colonies (NCM, 1999). Bacterial identification was performed according to taxonomic morphological and dyeing features, followed by catalase, coagulase, and biochemical test (OLIVER et al., 2004).

The somatic cell counting (SCC) data were distributed according to the $\mathrm{BE}$ results. Following this, a Kolmogorov-Smirnov test was applied, due to a non-parametric data distribution, for the calculation of medians. Differences between groups were compared with the Mann-Whitney test.

To determine SCC validity for the identification of infected quarters, its sensitivity and specificity were calculated at different cell thresholds. Sensitivity was calculated by the proportion of infected quarters with SCC values above the selected threshold; specificity was the proportion of negative samples with a SCC below the threshold. The concordance between SCCs and bacteriological examination was determined by the sum of the positive for each threshold, considering infected and uninfected, divided by the total number of positive samples, and multiplied by 100, in the study by Thrusfield (1995). Values for SCC validation comprised $0.2,0.4,0.6,0.8,1.0,1.5,2.0,3.0$, 4.0 , and $5.0 \times 10^{6}$ cells $/ \mathrm{mL}$.

\section{Results}

From the 20 cows included in this study, three udder quarters were lost and six were excluded due to bacterial contamination. Therefore, 71 samples of first-milking colostrum were processed in total. Bacterial growth was observed in 26 of the crops (36.62\%), of which only one exhibited a mixed growth of coagulase-negative Staphylococcus (CNS) and $S$. agalactiae. The microorganism groups detected are detailed in Table 1. The most predominant microorganism recorded was CNS (76.92\%), followed by Escherichia coli (11.54\%), S. agalactiae (3.85\%), and Streptococcus dysgalactiae (3.85\%). Table 2 presents SCCs; the bacteriologically negative and positive samples' SCCs range from 0.3 to $9.4 \times 10^{6}$ and 0.2 to $19.9 \times 10^{6}$ cells $/ \mathrm{mL}$, respectively. Median SCCs for cows with or without infection were 0.9 and $1.8 \times$ $10^{6}$ cells $/ \mathrm{mL}$, respectively $(\mathrm{p}=0.0451)$. 
Table 1 - Number of growths and relative values of isolated strains from bovine colostrum in Holstein cows during peripartum - Nova Odessa - 2014

\begin{tabular}{cccc}
\hline & Bacteria group & Number of growths (n) & Relative values (\%) \\
\hline & Coagulase-negative Staphylococcus & 20 & 76.92 \\
Isolated infection & Streptococcus agalactiae & 1 & 3.85 \\
& Streptococcus dysgalactiae & 1 & 3.85 \\
\hline Mixed infection & Escherichia coli & Coagulase-negative Staphylococcus + & 11.54 \\
$(>1$ bacterial genus) & Streptococcus dysgalactiae & 1 & 3.85 \\
\hline
\end{tabular}

Table 2 - Somatic cell count (cells $/ \mathrm{ml}$ ) variables recorded in colostrum samples testing negative and positive in bacteriological examination - Nova Odessa - 2014

\begin{tabular}{lcc}
\hline Statistical Analysis & positive BE & negative BE \\
\hline Median & $1.8 \times 10^{6 \mathrm{~A}}$ & $0.9 \times 10^{6 \mathrm{~B}}$ \\
Minimum & $0.2 \times 10^{6}$ & $0.3 \times 10^{6}$ \\
Maximum & $19.9 \times 10^{6}$ & $15.4 \times 10^{6}$ \\
Mean & $3.9 \times 10^{6}$ & $2.0 \times 10^{6}$ \\
Standard deviation & $4.9 \times 10^{6}$ & $2.6 \times 10^{6}$ \\
\hline
\end{tabular}

Capital letters in the same row indicate statistical difference $(p=0.0451)$

$\mathrm{BE}$, bacteriological examination

Table 3 - Epidemiological indicators for various somatic cell count thresholds in relation to the bacteriological examination of the bovine colostrum - Nova Odessa - 2014

\begin{tabular}{cccccc}
\hline Thresholds (cells/mL) & Sensitivity & Specificity & False Positive & False Negative & Concordance \\
\hline $0.2 \times 10^{6}$ & $100.0 \%$ & $100.0 \%$ & $100.0 \%$ & $0.0 \%$ & $36.6 \%$ \\
$0.4 \times 10^{6}$ & $92.3 \%$ & $97.8 \%$ & $97.8 \%$ & $7.7 \%$ & $35.2 \%$ \\
$0.6 \times 10^{6}$ & $92.3 \%$ & $88.9 \%$ & $88.9 \%$ & $7.7 \%$ & $40.8 \%$ \\
$0.8 \times 10^{6}$ & $73.1 \%$ & $68.9 \%$ & $68.9 \%$ & $26.9 \%$ & $46.5 \%$ \\
$1.0 \times 10^{6}$ & $65.4 \%$ & $46.7 \%$ & $46.7 \%$ & $34.6 \%$ & $57.7 \%$ \\
$1.5 \times 10^{6}$ & $57.7 \%$ & $28.9 \%$ & $28.9 \%$ & $42.3 \%$ & $66.2 \%$ \\
$2.0 \times 10^{6}$ & $42.3 \%$ & $22.2 \%$ & $22.2 \%$ & $57.7 \%$ & $64.8 \%$ \\
$3.0 \times 10^{6}$ & $26.9 \%$ & $20.0 \%$ & $20.0 \%$ & $73.1 \%$ & $60.6 \%$ \\
$4.0 \times 10^{6}$ & $26.9 \%$ & $17.8 \%$ & $17.8 \%$ & $73.1 \%$ & $62.0 \%$ \\
$5.0 \times 10^{6}$ & $23.1 \%$ & $8.9 \%$ & $8.9 \%$ & $76.9 \%$ & $66.2 \%$ \\
$10.0 \times 10^{6}$ & $15.4 \%$ & $2.2 \%$ & $2.2 \%$ & $84.6 \%$ & $67.6 \%$
\end{tabular}


The sensitivity (100 to $15 \%$ ), specificity (100 to $2.2 \%$ ), and false positive (100 to $2.2 \%$ ) decreased gradually as the SCC threshold increased (Table 3). In contrast, the proportion of false-negatives (0 to $84.6 \%$ ) increased from 0.2 to $10.0 \times 10^{6}$ cells $/ \mathrm{mL}$. The highest SCC and BE concordance threshold was 10.0 $\times 10^{6}$ cells $/ \mathrm{mL}$; however, the sensitivity $(15.4 \%)$, specificity $(2.2 \%)$, and false positive (2.2\%) rates were very low.

\section{Discussion}

Due to the high mammary infection rate in the immediate postpartum period, validation of mammary inflammation detection tests utilized during full lactation is required. Therefore, this study evaluated the application of colostrum SCCs for the detection of mammary gland inflammatory processes in periparturient Holstein cows.

The frequency of positive BE samples in colostrum $(36.62 \%)$ was similar to that reported by Oliveira et al. (2012) and Silva (2014) at $37.5 \%$ and $37.9 \%$, respectively. The present study was conducted at the same research center as that of Silva (2014) and may therefore explain the similarity in findings. In contrast to the present study, Gomes et al. (2011) reported a lower bacterial isolation rate in the first milking colostrum (19.3\%). This discrepancy could be attributed to the differences in the health management and rearing conditions employed between the two farms; the research of Gomes et al. (2011) was conducted at a highly technological farm with a rigorous mastitis control program and cows were treated and vaccinated during the dry period.

The main microorganism isolated from colostrum was CNS; however, none of the cows exhibited clinical manifestations consistent with inflammation processes. Intramammary infection caused by CNS in immunocompetent cows results in unapparent mastitis. Consequently, this bacterial group has received less attention compared with other mastitis causing pathogens such as $S$. aureus, Streptococcus spp., or coliforms (DJARBI et al., 2002).
The coagulase-negative Staphylococcus (CNS) is bacteria that belongs to the microbiota and may be present on the skin and teat cistern. However, immune imbalances in the mammary environment that occur during the transition period, especially the reduced number and functional activity of colostrum neutrophils (8-12\%), may favor microorganism multiplication and increase the rate of mammary infection. The outbreak of the disease depends on the immune adaptation ability of the MG in the immediate postpartum period; this may promote microorganism elimination or limit the infection to the mammary environment (GOMES et al., 2014).

The frequency of CNS (76.92\%) was higher than that reported by Dingwell et al. (2002), Odensten et al. (2007), Taponen et al. (2007), and Miranda-Morales et al. (2008) at $49.0 \%, 46.5 \%, 37.5 \%$, and $38.3 \%$, respectively. This is most likely due to the variations in hygienic conditions and other risk factors that favor the colonization of MG by CNS between studies. Hogan and Smith (2012) reported that the prevalence of intramammary infections caused by CNS was lower in quarters that received adequate cleaning and disinfection pre- and post- milking compared with those that were milked without being subjected to a cleaning process $(\mathrm{p}<0.05)$. The disinfection process is effective at limiting intramammary infection by reducing Staphylococcus spp. populations in teat skin (HOGAN; SMITH, 2012). This explains the high isolation rate of CNS in the colostrum of the present study, since the cows' teats were not subjected to a cleaning process during the dry season.

The colostrum SCC from healthy cows in this research $\left(0.9 \times 10^{6}\right.$ cells $\left./ \mathrm{mL}\right)$ was similar to that reported by McDonald and Anderson (1981) and Gomes et al. (2011) at $0.88 \times 10^{6}$ cells $/ \mathrm{mL}$ and $0.6 \times$ $10^{6}$ cells $/ \mathrm{mL}$, respectively. Jensen and Eberhart (1981) recorded a higher SCC $\left(2.6 \times 10^{6}\right.$ cells $\left./ \mathrm{mL}\right)$; however, these authors did not exclude samples from infected mammary glands. The SCC was higher in colostrum from cows subjected to bacterial isolation $\left(1.8 \times 10^{6}\right.$ cells $/ \mathrm{mL}$ ) than those obtained from MG secretions 
from uninfected cows $\left(0.9 \times 10^{6}\right.$ cells $\left./ \mathrm{mL}\right)$. Taponen et al. (2007) and Sampimon et al. (2010) also reported an elevated SCC in the milk samples from infected cows during full lactation; however, comparison of these findings is limited due to different lactation stages between studies.

Intramammary infection diagnosis tests must ideally possess high sensitivity for the detection of positive animals, excluding false-negative possibility. In this context, it is desirable for the test to identify uninfected animals while also excluding false negatives (THRUSFIELD, 1995). These characteristics are not associated with the colostrum SCC; therefore, it was not possible to establish a cellularity threshold to determine the presence or absence of intra mammary infection. The concordance between SCC and $\mathrm{BE}$ in this research was greater than $50 \%$ from 1,0 $\times 10^{6}$ cells $/ \mathrm{mL}$; however, the sensitivity and specificity rates were very low for all thresholds above this value. Two factors to be considered in the interpretation of epidemiological indicators comprise the influence of the colostrogenesis process and the presence of mammary infection. Dohoo and Leslie (1991) reported greater sensitivity (72\%) and specificity (85\%) for a $0.2 \times 10^{6}$ cells $/ \mathrm{mL}$ threshold in the milk from lactating cows. In contrast, these authors reported low sensitivity and specificity for SCC when the herd exhibited a high prevalence of CNS and Corynebacterium bovis infection. This information is favorable for the interpretation of the epidemiological indicators in the present study because most of the strains were isolated from the CNS group. Therefore, the slight SCC increase in infected MG, concomitant with the physiological changes of mammary secretion in the peripartum, precluded the selection of a suitable cell threshold. Consequently, it is not possible to determine a SCC threshold for the evaluation of infection occurrence using the sensitivity and specificity indices alone.

Sargeant et al. (2001) analyzed colostrum and milk samples from 131 cows in postpartum and observed a reduction in SCC during the first 10 days post-partum in uninfected quarters. This trend coincided with an increase in sensitivity (57.4\%) and specificity (72.3\%) indices on the fifth day postpartum when the threshold adopted was 100,000 cells $/ \mathrm{mL}$. This information is in agreement with the findings reported in the current study and highlights the need for further evaluation of other complementary tests for the early diagnosis of mastitis in the immediate postpartum period.

Based on these results, it can be concluded that the SCC increases prior to MG infectious processes and that CNS are predominately responsible for this increase. However, physiological changes resulting from colostrogenesis results in poor concordance between the SCC and BE of colostrum.

\section{Acknowledgements}

We would like to thank the Foundation for Research Support of the State of São Paulo Research for financially supporting for this research: 2010/15865-9. 


\section{References}

BAUMRUCKER, C. R.; BRUCKMAIER, R. M. Colostrogenesis: IgG1 transcytosis mechanisms. Journal of Mammary Gland Biology and Neoplasia, v. 19, n. 1, p. 103-117, 2014. doi: http://dx.doi.org/10.1007/s10911-0139313-5.

DENTINE, M. R.; McDANIEL, B. T. Variation of edema scores from herd-year, age, calving month, and sire. Journal of Dairy Science, v. 66, n. 11, p. 2391-2399, 1983. doi: http://dx.doi.org/10.3168/jds.S0022-0302(83)82097-9.

DINGWELL, R. T.; DUFFIELD, T. F.; LESLIE, K. E.; KEEFE; G. P.; DESCOTEAUX, L.; KELTON, D. F.; LISSEMORE, K. D.; SCHUKKEN, Y. H.; DICK, P.; BAGG, R. The efficacy of intramammary tilmicosin at drying-off, and other risk factors for the prevention of new intramammary infections during the dry period. Journal of Dairy Science, v. 85, n. 12, p. 3250-3259, 2002. doi: http://dx.doi.org/10.3168/jds.S0022-0302(02)74413-5.

DJARBI, B.; BAREILLE, N.; BEAUDEAU, F.; SEEGERS, H. Quarter milk somatic cell count in infected dairy cows: a meta-analysis. Veterinary Research, v. 33, n. 4, p. 335-357, 2002. doi: http://dx.doi.org/10.1051/vetres:2002021.

DOHOO, I. R.; LESLIE, K. E. Evaluation of changes in somatic cell counts as indicators of new intramammary infections. Preventive Veterinary Medicine, v. 10, n. 3, p. 225-237, 1991. doi: http://dx.doi.org/10.1016/01675877(91)90006-N.

GOMES, V.; BACCILI, C. C.; SILVA, C. P. C.; PINTO, V. S. C.; SILVA, B. T.; POZZI, C. R.; RIBEIRO, C. P.; PITUCO, E. M. Humoral immunity assessment in calves born to cows immunized with inactivated vaccine for Bovine Herpesvírus 1 and Bovine Viral Diarrhea virus. Acta Scientiae Veterinariae, v. 42, n. 1239, p. 1-7, 2014.

GOMES, V.; MADUREIRA, K. M.; DELLA LIBERA, A. M. M. P.; BLAGITZ, M. G.; ALVES, M.; BAPTISTELLA, F.; BENESI, F. J. Cell dynamics of Holstein cow colostrum immediately after parturition. Arquivo Brasileiro de Medicina Veterinária e Zootecnia, v. 63, n. 5, p. 1047-1053, 2011. doi: http://dx.doi.org/10.1590/S0102-09352011000500001.

HODGKINSON, A. J.; CARPENTER, E. A.; SMITH, C. S.; MOLAN, P. C.; PROSSER, C. G. Adhesion molecule expression in the bovine mammary gland. Veterinary
Immunology and Immunopathology, v. 115, n. 3-4, p. 205-215, 2007.2 doi: http://dx.doi.org/10.1016/j.vetimm.2006.10.020.

HOGAN, J.; SMITH, K. L. Managing environmental mastitis. Veterinary Clinics of North America: food animal practice, v. 28, n. 2, p. 217-224, 2012. doi: http://dx.doi.org/10.1016/j.cvfa.2012.03.009.

JENSEN, D. L.; EBERHART, R. J. Total e differential cell count in secretions of the nonlactating bovine mammary gland. American Journal of Veterinary Research, v. 42, n. 5, p. $743-747,1981$.

MADDOX, J. F.; AHERNE, K. M.; REDDY, C. C.; SORDILLO L. M. Increased neutrophil adherence and adhesion molecule mRNA expression in endothelial cells during selenium deficiency. Journal of Leukocyte Biology, v. 65, n. 5 , p. $658-664,1999$.

McDONALD, J. S.; ANDERSON, A. J. Total and differential somatic cell counts in secretions from noninfected bovine mammary glands: the peripartum period. American Journal of Veterinary Research, v. 42, n. 8, p. 1366-1368, 1981.

MIRANDA-MORALES, R. E.; ROJAS-TREJO, V.; SEGURA-CANDELAS, R. CARRILLO-CASAS, E. M.; SANCHEZ-GONZALES, M. G.; CASTOR, R. S.; TRIGOTAVERA, J. Prevalence of pathogens associated with bovine mastitis in bulk tank milk in Mexico. Annals of the New York Academy of Sciences, v. 1149, p. 300-302, 2008. doi: http://dx.doi.org/10.1196/annals.1428.012.

NATIONAL MASTITIS COUNCIL (NCM). Laboratory handbook on bovine mastitis. Madison WI: National Mastitis Council, 1999. 208 p.

ODENSTEN, M. O.; BERGLUND, B.; PERSSON WALLER, K.; HOLTENIUS, K. Metabolism and udder health at dryoff in cows of different breeds and production levels. Journal of Dairy Science, v. 90, n. 3, p. 1417-1428, 2007. doi: http://dx.doi.org/10.3168/jds.S0022-0302(07)71627-2.

OLIVEIRA, J. M. B.; VANDERLEI, D. R.; MORAES, W. S.; BRANDSPIM, D. F.; MOTA, R. A.; OLIVEIRA, A. A. F.; MEDEIROS, E. S.; PINHEIRO JUNIOR, J. W. Risk factor related to bovine mastitis in the micro-region of Garanhuns, Pernambuco, Brazil. Pesquisa Veterinária 
Brasileira, v. 32, n. 5, p. 391-395, 2012. doi: http://dx.doi.org/10.1590/S0100-736X2012000500005.

OLIVER, S. P.; HOGAN, J. S.; JAYARAO, B. M.; OWENS, W. E. Microbiological procedures for the diagnosis of bovine udder infection and determination of milk quality. $4^{\text {th }}$ ed. Verona, WI: National Mastitis Council, 2004. 47 p.

RAJALA-SCHULTZ, P. J.; GRÖHN, Y. T.; McCULLOCH, C. E.; GUARD, C. L. Effects of clinical mastitis on milk yield in dairy cows. Journal of Dairy Science, v. 82, n. 6, p. 1213-1220, 1999. doi: http://dx.doi.org/10.3168/jds.S00220302(99)75344-0.

ROSENFELD, G. Corante pancrômico para hematologia e citologia clínica: nova combinação dos componentes de May-Grunwald e do Giemsa num só corante de emprego rápido. Memórias do Instituto Butantan, v. 20, n. 1, p. 329-334, 1947.

SAMPIMON, O.; BORNE, B. H. P.; SANTMANBERENDS, I.; BARKEMA, H. W.; LAM, T. Effect of coagulase-negative staphylococci on somatic cell count in Dutch dairy herds. Journal of Dairy Research, v. 77, n. 3, p. 318-324, 2010. doi: http://dx.doi.org/10.1017/S0022029910000191.

SARGEANT, J. M.; LESLIE, K. E.; SHIRLEY, J. E.; PULKRABEK, B. J.; LIM, G. H. Sensitivity and specificity of somatic cell count and California mastitis test for identifying intramammary infection in early lactation. Journal of Dairy Science, v. 84, n. 9, p. 2018-2024, 2001. doi: http://dx.doi.org/10.3168/jds.S0022-0302(01)74645-0.

SILVA, C. P. C. Imunidade inata no sangue e secreção mamária de vacas Holandesas no período periparto. 2014. 142 f. Dissertação (Mestrado em Ciências) Faculdade de Medicina Veterinária, Universidade de São Paulo, São Paulo, 2014.

SILVA, C. P. C.; BALDACIM, V. A. P.; REIS, J.F.; NOVO, S. M. F.; SANTOS, O.; STRICAGNOLO, C. R.; HURLEY, D. J.; GOMES, V. Proportion and functional activity of $\mathrm{CH} 138+$ neutrophils in bovine colostrum and milk through natural exposure to mastitis causing bacteria. In: WORLD BUIATRICS CONGRESS, 28., 2014, Australia. Proceedings... Australia: Australian Veterinary Association, 2014.

TAPONEN, S.; KOORT, J.; BJORKROTH, J.; SALONIEMI, H.; PYORALA, S. Bovine mastitis caused by coagulasenegative staphylococci may persist. In: INTERNATIONAL SOCIETY FOR ANIMAL HYGIENE, 13., 2007, Tartu. Proceedings... Tartu, Estonia: International Society for Animal Hygiene, 2007. p. 476-479.

THRUSFIELD, M. V. Veterinary epidemiology. $2^{\text {nd }}$ ed. Cambridge: Blackwell, 1995. 479 p. 